\title{
Digital Economy in the Context of Phylogenesis of Innovation and Market Development
}

\author{
P.V. Stroev, D.V. Firsov and S.B. Reshetnikov
}

Financial University under the Government of the Russian Federation, Moscow, Russia

\begin{abstract}
Understanding the phylogenetic origin of a concept of innovation stands as the main precipice in establishing a sustainable concept of innovation. And as a scientific direction in studying emergence, distribution and commercialization of innovations. Primary Novelty of present article is expressed through analysis of neoindustrialization as a process of transition to a new economic paradigm through renewal of industrial infrastructure and its form of organization in a Technetronic phase of development. Comparative, comprehensive and factor analysis stands as the main methodology for the present article. Primary data consists of government and commercial statistics. The empirical analysis shows the importance of the vertically integrated structures in the course of new cluster development as well as their weight and importance in the development of the modern digital economy.

Results of a research of Economist Intelligence Unit in 82 countries of the world say that such countries as Mexico or China, quickly improve the skills in the field of innovations. The research allowed being elicited one remarkable fact: the countries with the average level of economic welfare have additional benefits that introduction of domestic innovative developments stimulates also faster development of foreign experience.
\end{abstract}

Keywords: Digital economy, clusters, innovation, E-governance, E-health, E-education, E-business.

\section{INTRODUCTION}

Fundamental systemic results are crucial for the creation of adequate tools for the development and management of not only the markets that come with digitalization, but also the digital economy as a whole. That is why it is crucial to develop a phylogenetic understanding of innovation.

One of the key features of the digital economy is its cluster properties, which lead to increase in the number of horizontal connections, or links, which in turn leads to a rapid spread of innovation within economic system as a whole. That is why the cluster is often regarded as an optimal element of systems that form breakthrough technologies and advanced products. That Is why it crucial to analyse current trends and practices in cluster formation. In the present study, we examine leading digital economies as well as Germany's clusters and what the role they play in the digital economy.

\section{INNOVATION THEORIES}

Scientists such as W. Abernathy, K. Kristen, C. Clarke, S.G. Falco emphasised that the development of the world economy will be determined by innovation as a driving factor in international competition. This feature is especially emphasised in hi-tech development, in

*Address correspondence to this author at the Financial University under the Government of the Russian Federation, Moscow, Russia;

Tel: +79175242043; E-mail: reshetnikovst@gmail.com

JEL classification: B25, O10, O14, F2.

\# Research is conducted with the assistance of the Russian Foundation of Basic Research (RFBR), No. 17-02-00269. which innovation and expansion of the market constitute a significant factor of development.

Innovation is a new field of scientific knowledge that appeared in the early twentieth century in the field of economic sciences. It studies the patterns and features of innovations. The subject of innovation is an innovative process that includes creation, distribution and use of innovations. The result of this process is innovation.

A single definition of "innovation" does not exist, since many authors considered different aspects of this phenomenon. Among the most significant are: J. Schumpeter, N.D. Kondratieva, A.I. Prigogine, B. Twiss, G. Mensha, S.Y. Glazyev, L.S. Blyakhman, K. Freeman, Yu.V. Yakovtsa, B.Santo, E.G. Yakovenko, F.Valenta, E.A. Utkin, E. Rogers, R.A. Fatkhudinova.

Conditionally, we can distinguish three basic principles for determining innovation:

- Innovation as a set of changes and novelties inventions (J. Schumpeter, F. Valenta, L.S. Blyakhman, Y. Yakovets);

- Innovation as a process of change (S.Y. Glazyev, B. Twiss);

- Innovation as the final result of the change (E.A. Utkin, R.A. Fatkhudinov, I.N. Molchanov).

We consider it necessary to take into consideration the definition of innovation in all the aspects mentioned above. 
Only at the beginning of the twentieth century, innovations began to correlate with economic development. Works of N.D. Kondratiev, who was devoted to the study of special technological cycles, formed during the introduction of basic innovations.

The basic concepts of the theory of innovation were derived by J.A. Schumpeter, who defined them as new combinations of resource use that leads to success in the market. An essential point of his research is the emphasis on the role of entrepreneurship in innovation. For him, entrepreneurs are "economic entities whose function is the implementation of new combinations, and which act as its active element." At the same time, technical innovations are regarded as an additional economic means for obtaining competitive advantages, and therefore profits. Profit is essentially the result of the implementation of new combinations; without development, there is no profit; without profit, there is no development.

In this way, we can view innovation as a complex definition involving many elements. Innovation is a social, technical and economic process that, through the practical use of ideas and new technologies, leads to the creation of innovative products that are used to obtain a positive economic effect.

In modern science, we see a variety of interpretations of the concept of "innovation" and "innovator."

Some researchers believe that innovation is a process (B. Santo, V. Rappoport, B. Twiss). B. Santo defines innovation as: "Public - technical - economic process, which through the practical use of ideas and inventions leads to the creation of the best in its properties of products, technologies."

Other researchers (E.A. Utkin, N.I. Morozova, G.I. Morozova, V.G. Medynsky) understand innovation as "an object introduced into production as a result of the research or discovery made, qualitatively different from the previous analogue".

Such scientists as F.G. Gurvich, N.M. Avsyannikov, S.D. Beshelev defines innovation as the end result: "Innovation is the result of practical or scientific and technological development of innovation." Here we can also include researchers who focus their attention specifically on the economic effect of innovation, for example, Yu.P. Morozov gives the following definition of innovation: "Innovation in the broad sense refers to the profitable use of innovations in the form of new technologies, types of products and services, organizational, technical and socio-economic solutions of production, financial, commercial, administrative or other nature."

As we can see, establishing a complete definition of innovation is practically impossible as it varies widely, what we can establish - is the extremely theorised overview of the matters at hand. In the modern context, the definition of innovation is practically absent, and even though theoretical basis rarely has any impact on independently developing systems, in the long run, an absence of concrete definitions can result in a setback for science as a whole.

\section{DIGITAL ECONOMY INFLUENCE CALCULATION}

$21^{\text {st }}$ century established itself as a critical period in the formation of a new technological paradigm. Rapid development of IT, medicine and manufacturing opened new fields of competition between national economies, that in turn posed new necessities and challenges for a scientific community in establishing an adequate framework for fostering a new type of economy that promises to open a new page for humanity. This, widely known as "digital", economy was first formulated in Japan in the 1990s amidst Japanese recession, later this term was adopted and used by Don Tapscott in his book "The Digital Economy: Promise and Peril in the Age of Networked Intelligence", in its first iteration digital economy was mostly used in tandem with internet and E-commerce, and was a first groundwork on how internet will change the way we do business. Later in 2001, Thomas Mesenbourg formulated the domains of Digital economy that served as «internal industries»:

1. E-business infrastructure (hardware, software, telecoms, networks, human capital, etc.),

2. E-business (how business is conducted, any process that an organisation conducts over computer-mediated networks),

3. E-commerce (transfer of goods, for example when a book sold online).

Since then the digital economy made a significant stride in its development, lightning speed of new means of communication and structure no longer, allow us to divide it based on sectoral principles. Nowadays we have to look at it as a first iteration of ever so complex singularity that presents itself as a new infrastructure of the future. 
As of 2018 worlds, digital economy is valued at 3 trillion dollars, which is already more than United Kingdom's GDP, which is valued at a 2.6 trillion and soon promises to overtake Germany at 3.4 trillion. However, the most impressive thing is that all that value was created in a mere 20 years since the launch of the Internet.

With such significant and explosive growth, it is no surprise that countries are trying to use it to increase their competitive advantage in international markets. Right now drafted policies and established instruments are relatively new and unpolished, in many regards they are pioneering development, and at the forefront of this innovation, we can see only a handful of countries that can show real tangible results.

The leader among them is, not surprisingly - the United States, that managed to almost double the gross output of the digital economy in just a little over a decade Chart 1.

Another spectacular example is Germany. In many aspects Germany is considered as a leader in establishing sustainable diffusion of digital economy amongst its business entities. According to 2018 Federal Ministry for Economic Affairs and Energy report on digital monitoring, approximately $7 \%$ of domestic companies are considered "digital pioneers" and $32.4 \%$ as "digitally advanced", meaning that almost $40 \%$ of Germany's economy is internet based. As a result, in 2018 percentage of companies that generated more than $60 \%$ of their revenue through digital products and services broke 25 percentile mark, which is not surprising, as approximately $81 \%$ of the populace (62 million people) use the internet daily Chart 2.

Additionally report outlines a list of innovative applications, such as Cloud computing, Internet of things, Smart services, Robotics \& sensors, 3D printing, big data and so forth.

These applications form what is known as "breakthrough digital technologies", these technologies are universally regarded as a foundation when it comes to fostering national digital economies.

Cloud computing and big data are the technologies that advance a company's level of digitalisation the most. However, while cloud-based services are frequently used $(43 \%)$, only $9 \%$ of companies currently use driver technology that enables the analysis of large datasets. The importance of the different innovative applications differs from sector to sector: While cloud

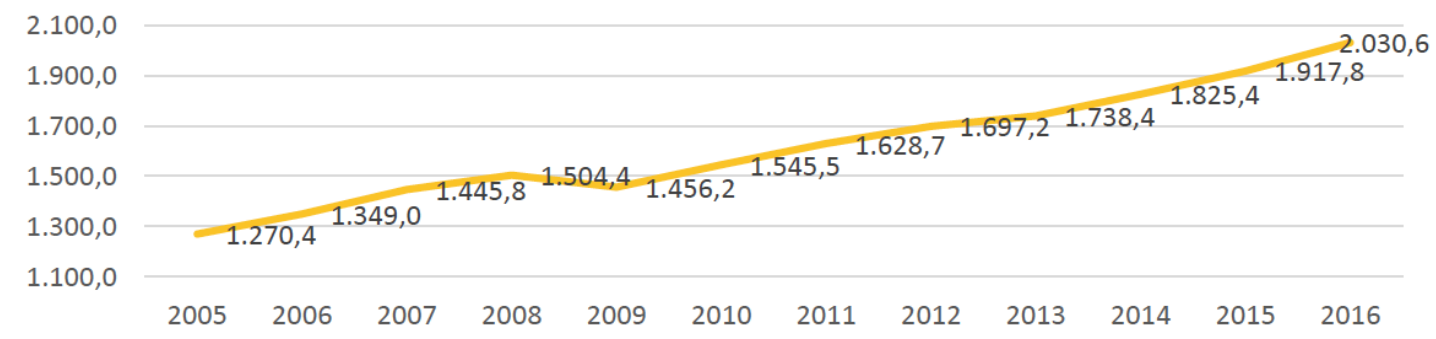

Chart 1: Digital economy gross output in the USA (billions of dollar).

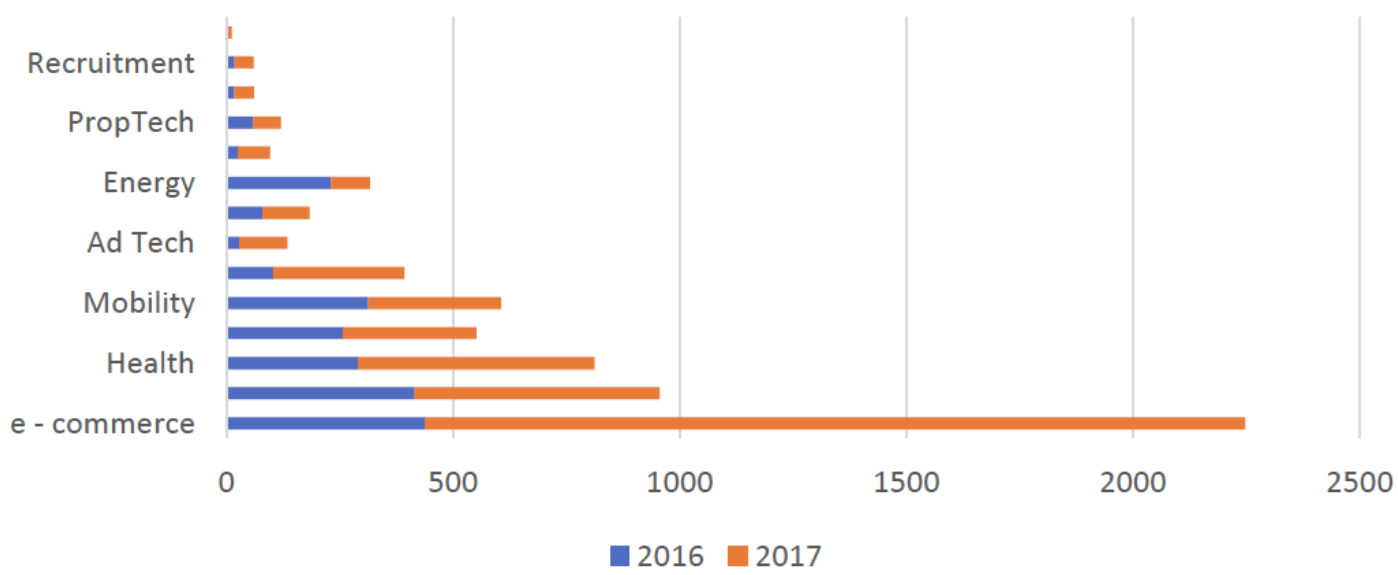

Chart 2: Digital economy financing in Germany (mil. euros). 
Table 1: Biggest Clusters of Germany

\begin{tabular}{|c|c|c|c|c|}
\hline CLUSTER & ABOUT & HISTORY & SUCCESS FACTORS & CHALLENGES \\
\hline $\begin{array}{l}\text { Bosch Chip } \\
\text { Manufacturing } \\
\text { Plant }\end{array}$ & $\begin{array}{l}\text { Bosch announced the } \\
\text { construction of a new } \\
\text { semiconductor plant in } 2017 \text {. } \\
\text { The company is traditionally } \\
\text { known as a maker of } \\
\text { mechanical automotive parts } \\
\text { such as braking systems and } \\
\text { combustion engines, but is } \\
\text { also a long-time software } \\
\text { developer and is increasingly } \\
\text { investing in innovative } \\
\text { technologies to keep up with } \\
\text { the changing nature of driving. } \\
\text { For almost } 50 \text { years, Bosch } \\
\text { has been developing and } \\
\text { manufacturing microelectronic } \\
\text { components and systems. } \\
\text { Bosch developed the } \\
\text { microfabrication technique for } \\
\text { microelectromechanical } \\
\text { systems (MEMS) and today is } \\
\text { the global market leader. } \\
\text { According to the German } \\
\text { company, every car sold } \\
\text { globally contained an average } \\
\text { of nine chips made by Bosch } \\
\text { in } 2016 \text {. }\end{array}$ & $\begin{array}{c}\text { •Heart of Silicon } \\
\text { Saxony cluster, part of } \\
\text { Silicon Europe } \\
\text {-Cluster covering the } \\
\text { whole value chain•The } \\
\text { core of the ICT } \\
\text { Saxony Cluster }(2,100 \\
\text { enterprises and } \\
51,000 \\
\text { employees)·Strong } \\
\text { research and } \\
\text { university landscape } \\
\text { (13 Fraunhofer } \\
\text { Institutes and nine } \\
\text { universities) supplying } \\
\text { the region with skilled } \\
\text { potential employees } \\
\text { •Functioning } \\
\text { technology transfer } \\
\text { structure•Strategic } \\
\text { cooperation with local, } \\
\text { national, and } \\
\text { European } \\
\text { authorities•A key area } \\
\text { in "High-tech Strategy } \\
\text { for Germany" and } \\
\text { "Innovation strategy" } \\
\text { and in high propriety } \\
\text { foe, EU-funding } \\
\text { focused on "smart } \\
\text { specialisation." }\end{array}$ & $\begin{array}{c}\text {-Location: Dresden, Germany } \\
\text {-EUR 1.1bn investment (largest in } \\
\text { Bosch's history) } \\
\text {-Majority of the investment from } \\
\text { Bosch and the rest from national } \\
\text { and European Union subsidies } \\
\text {-Approx. } 15,000 \mathrm{~m}^{2} \text { shopfloor } \\
\text { space } \\
\text { - Up to } 700 \text { collaborators working } \\
\text { on site } \\
\text {-Bosch holds more than 1,000 } \\
\text { patents and patent applications } \\
\text { related to MEMS technology } \\
\text {-Built to satisfy the demand } \\
\text { generated by the growing number } \\
\text { of the internet of things (loT) and } \\
\text { mobility applications }\end{array}$ & \\
\hline
\end{tabular}

computing and big data are proving themselves to be significant drivers of digitalisation in the service sector in particular, in the industry, it is the"internet of things" that is most important. It seems for now usage of big data is limited to ICT companies, as the ICT sector remains a pioneer of digitalisation. In order to facilitate additional diffusion of big data in different sectors of economy, Federal Ministry for Economic Affairs and Energy jumpstarted a new technological program "Smart Data - Innovations in Data", with over 55 million 
in funding (apart from 30 millions of government funding, the program includes 25 million euros that are provided by private companies and organizations). The technology program focusses on the usage of smart data in the areas of industry, mobility, energy and health. Its objective is to give impetus to the development of legally compliant, secure and viable solutions. With expected projection in the big data market to exceed 86 billion dollars by 2026, it contains one of the biggest potentials for the digital economy of the future.

What is important to note, is how these technologies manifest in new principles of organisation. The most prominent form of technological development that manifests in the $21^{\text {st }}$ century is research-intensive clusters, regions with a high density of researchoriented organisations.

The efficiency of the production process depends on the effectiveness of the interaction between economic agents and accompanying structures. Practice shows that the most effective forms of organisation, especially when it comes to researchintense industries are in fact clusters.

The concept of cluster organisation of economic relations has become widespread in the economic literature, but there is no single generally accepted concept. The origin of cluster research is the American scientist Michael Porter, who heads Harvard's Business School Administration Department. In his book "Competition" he derives basic definitions of clusters.

Porter's clusters are:

1. Geographically distributed groups of enterprises, specialised suppliers of components and services in related areas, that are competing in these areas, but at the same time work together.

2. Geographically adjacent interrelated enterprises that operate in a certain area and mutually complement each other.

3. A system of interconnected enterprises and organisations whose total economic power exceeds the sum of the components.

4. The form of spatial organisation, which in its essence can be more effective with respect to individual elements of production, if local competitive suppliers are available.

5. A network form that is observed within a geographical region where the compact arrangement of enterprises and organisations ensures the presence of certain forms of community and increases the level and frequency of their interaction.

6. A way of structuring and understanding the economy, theory and practice of economic development, as well as the development and shaping of public policy.

Clusters are different in their characteristics and features. As a rule, they differ in size, level of internal development and breadth of coverage. Some clusters consist exclusively of small firms, while in others, TNCs, governments and natural monopolies take part. As a rule, cluster development is directly related to the number of internal and external links and intersectoral interactions. In developed clusters, vendor bases are more specialised yet work on similar production factors.

As a rule, the advantages of enterprises in the cluster are higher due to the synergistic effect. In addition, the competitiveness of individual firms is growing due to the diffusion of innovation, because innovations are rapidly spreading through a large number of communications between individual elements of the system.

Clusters are riddled with two driving forces competition and cooperation. The intensity of the struggle for the market inside the cluster is higher, but the partnership relations are much easier to achieve. At the same time, the cluster itself often forms its local labour market, raw materials and production components.

The saturated competitive environment of a cluster reduces barriers for both entry and exit. At the same time, the organisational structure of enterprises becomes very plastic - enterprises appear, merge or disappear continuously. As a rule, enterprises are usually structured into grids of overlapping relationships between corporations, individual entrepreneurs and state structures.

All these characteristics and definitions emphasise the place of cluster structures in the digital e-economy since the cluster is not just a form of business organisation, but also a form of social interaction and reproduction. This can be traced to both - German model of "Industry 4.0" and in the American model of "Industrial Internet".

In the past decade, the number of such clusters increased tenfold. Right now, there are over 90 active 
clusters in Germany alone; a key purpose of such entities is to accelerate the process of making new technological products. Establishing such regions is incredibly capital and research intensive and require long-term strategic interest and commitment. That is why Germany pioneered special programs to support them not only financially, but politically as well. Most prominent and well-known program - "go-cluster programme."

Offers various benefits and advantages. These advantages include:

- $\quad$ participation and higher visibility in government economic initiatives

- increased national and international visibility to decision-makers representing government, business and administration

- networking activities with the most effective innovation clusters from Germany and Europe

- individual counselling of cluster management among others on the issues of strategy development

- $\quad$ entitlement to apply for funds

In addition, even though clusters that apply for the program need to meet specific, often quite strict criteria, benefits that come from participating in this national program vastly outweigh all the administrative and financial expenses.

Programs principles of professional, effective, demand-driven services.

As an example, Russian 2017 program of "Digital economy of the Russian Federation" outlines these same technologies as "principal" technologies, in other words - primary tools in establishing first level digitalisation.

Oddly enough, similarities in developing digital economies can be established between all countries and among all principal technologies. For the purpose of brevity we should examine two major centres Germany and Japan, and although we can argue that Germany is a part of European Union and cannot be considered economically singular, an independent entity we will just have to adequately adjust what indexes, criteria and indicators we use.

Japan was always at the forefront of innovation, it is lack of natural recourses, and strong national stance established them as a technological superpower not only in the $20^{\text {th }}$ but in the $21^{\text {st }}$ century as well, and by the looks of it they are not slowing down. Being one of a few countries where enterprise usage of the internet is at a staggering $99.9 \%$ rate, its IT diffusion is amongst highest in the world, and although their relative population usage of the internet is lower than Germanys ( $70 \%$ of Japan against $81 \%$ of Germany) their average e-commerce sale per digital buyer is significantly higher (€1633 Japan vs $€ 1500$ Germany), and all that with rapidly aging population.

E-commerce is one of the main domain of present digital economy, as it is easily measurable and projectable. The Japanese e-commerce market is relatively mature and accounts for 77 billion Euros. In comparison Germanys, e-commerce market accounts for 59.7 billion euros. Moreover, its market does not limit more than that japans e-commerce. According to 2018 LSE Regulatory Assessment \& FDI Review, Chinese consumers spent more than $¥ 1$ trillion (US\$ $9.5 \mathrm{bn}$ or $€ 7.7 \mathrm{bn}$ ) on Japanese merchandise in 2016 via cross-border e-commerce platforms, which are projected to more than double in 2019. What is interesting to note, is that legislative development and framework is one of a few distinct differences in managing digital economies.

Surprisingly enough vast similarities in the development of technologies themselves do not mean similarities in laws, which results in protectionist measures across certain regions. For example, China considers e-commerce to be a telecom service, which in turn imposes licensing requirements, which have to be approved by the government, in Japans case only one company has been approved.

According to numerous reports and studies, legislative bounds are to be considered most impactful hold back for digital economy throughout the world. The main reason lies not in the development of technologies themselves, but in a corresponding trade that acts as a precursor in the development of these technologies. Right now, we can observe a distinct lack of binding global rules in e-commerce, which allowed many countries to roll back on foreign participation in their economies, effectively imposing a sort of embargo on goods and services from the outside world. For the most part its really difficult to quantify impact of this legislation as there are few tools that can do so, one of the proposed tools is ECIPE digital trade restrictiveness index which measures the restrictiveness and discrimination of foreign entities in 
the digital economy, amongst measured categories are: Fiscal restrictions \& market access, establishment restrictions, restrictions on data and trading Restrictions Table 2.

Table 2: ECIPE Digital Trade Restrictiveness Index

\begin{tabular}{|c|c|c|}
\hline RANK & COUNTRY & INDEX \\
\hline \hline 1 & CHN & 0.70 \\
\hline 2 & RUS & 0.46 \\
\hline 3 & IND & 0.44 \\
\hline 4 & IDN & 0.43 \\
\hline 5 & VNM & 0.41 \\
\hline 6 & BRA & 0.40 \\
\hline 7 & TUR & 0.38 \\
\hline 8 & ARG & 0.38 \\
\hline 9 & FRA & 0.36 \\
\hline 10 & THA & 0.35 \\
\hline
\end{tabular}

Unfortunately, present index tends to be incredibly biased as restrictions on data and trade are heavily dependent on researchers subjective opinion. As a result, for now, our primary tool in determining trends and vectors of development will have to be limited to a case by case review of already existing legislative initiatives and their direct contributions to the industry as a whole.

\section{CONCLUSIONS}

Our study shows that the impression of dominance by Germany and Japan in the digital economy also holds true when using a standardised and reproducible measurement approach. Because of this, policymakers in other countries, particularly in Germany, should be alarmed by these findings.

In Germany, the portfolio of large firms only consists of rather old companies with a long tradition. New players, such as Rocket Internet SE (which during the past 12 months has rather been shrinking) from Berlin, do not even reach the top three. Other studies have found that Berlin has the highest number of new ventures in Germany. However, this is not yet visible in the market capitalisation of the digital sector, which consists mainly of the three strong traditional players.

An understanding of the digital economy in this study should, however, not be concluded, as opposite cases are also likely possible.

\section{REFERENCES}

Ballas, D and Clarke G P (2001a) „Modelling the local impacts of national social policies: a spatial microsimulation approach", Environment and Planning C: Government and Policy, 19(4), 587-606. https://doi.org/10.1068/c0003

eMarketer, Worldwide Retail and E-commerce Sales, 2018. URL: eMarketer, Worldwide Retail and E-commerce Sales, 2018.

European Commission, Digital Single Market Strategy, May 2015. URL: $\quad$ https://ec.europa.eu/commission/sites/betapolitical/files/2-years-on-dsm_en_0.pdf.

Glazyev S. Yu. Theory of long-term technical and economic development. - M, 1993.

James M Utterback and William J Abernathy A dynamic model of process and product innovation Omega, 1975, vol. 3 , issue 6, 639-656 https://doi.org/10.1016/0305-0483(75)90068-7

Kondratyev N.D. Problems of economic dynamics. - M, 1989.

Lee-Makiyama, Ferracane, China's Technology Protectionism and its Non-negotiable Rationales, ECIPE, 2017.

O"Donoghue C, Lennon J and Hynes S (2009) "The Life-Cycle Income Analysis Model (LIAM): A Study of a Flexible Dynamic Microsimulation Modelling Computing Framework", International Journal of Microsimulation, 2(1), 16-31. (http://www.microsimulation.org/lJM/ V2_1/IJM_2_1_2.pdf) [accessed 25 July 2018]

Regulatory Assessment \& FDI Review. URL: http://www.lse.ac.uk/business-andconsultancy/consulting/assets/documents/at-the-nexus-oftrade-and-investment-sectoral-paper-digital-economy.pdf.

Smith D M, Clarke G P and Harland K (2009) „Improving the synthetic data generation process in spatial microsimulation models", Environment and Planning A, 41(5), 1251 - 1268. https://doi.org/10.1068/a4147

Statistical Handbook of Japan 2017. URL: http://www.stat.go.jp/english/data/handbook/c0117.html

Yamagata, Adways to expand analysis of China cross-border ecommerce, Nikkei Asian Review, March 13, 2017.

平成26年版ICT国際競争力指標 Ministry of Internal Affairs and Communications

URL:http://www.soumu.go.jp/main_content/000319905.pdf.

Received on 12-03-2019

Accepted on 11-06-2019

Published on 06-08-2019

DOI: https://doi.org/10.6000/1929-7092.2019.08.35

(C) 2019 Stroev et al.; Licensee Lifescience Global.

This is an open access article licensed under the terms of the Creative Commons Attribution Non-Commercial License (http://creativecommons.org/licenses/by-nc/3.0/) which permits unrestricted, non-commercial use, distribution and reproduction in any medium, provided the work is properly cited. 